Ethiopian Journal of Environmental Studies \& Management 9(5): 567 - 578, 2016.

ISSN:1998-0507

doi: http://dx.doi.org/10.4314/ejesm.v9i5.4

Submitted: February 07, 2016

Accepted: September 07, 2016

\title{
AN ASSESSMENT OF HOUSEHOLD WATER ACCESSIBILITY IN THE SOUTHERN PART OF NIGER STATE, NIGERIA
}

*DANGANA, K. AND MUHAMMAD, L.H.

Department of Geography, Ibrahim Badamasi Babangida University Lapai Niger State, Nigeria

\begin{abstract}
The study examined the determinants of household water accessibility in Southern part of Niger State, Nigeria. Data for the study was obtained from primary and secondary sources using questionnaire, interview, Personal observation and documents. 1,192 questionnaires were administered; sampling techniques adopted are combination of purposive, stratified and simple random. Purposive sampling technique was used to determine sample frame; sample unit was determined using stratified sampling method and simple random technique was used in administering questionnaires. The result was analyzed within the scope of "WHO" water accessibility indicators using descriptive statistics. Major sources of water in the area are well; boreholes and streams. These sources account for over $90 \%$ of household's water. Household water accessibility is affected mainly by the factors of distances, time spent to obtain water, low income status of the majority of respondents to access modern water infrastructure, and to a lesser extent household size. Recommendations includes, all tiers of government to intensify efforts in providing water infrastructures and maintain existing ones through budgetary provisions, and communities and individual should organize fund raising forum, so as to raise fund to improve water infrastructures in the area.
\end{abstract}

Key Words: Determinants, Accessibility, Indicators, Distances, Interview

\section{Introduction}

Life, health and hygiene all depend on an access to a quantitative and qualitative supply of drinking water. The adequacy in the supply of good drinking water determines health; welfare etc. In spite of this, however, the existing situation of pipe borne water supply in most part of the world is largely inadequate to meet the ever increasing demands of the population, (WWAP, 2003).
Pressures on water resources are increasing mainly as a result of human activities, namely urbanization, population growth, increased living standard, growing competition for water and pollution. These are aggravated by climate change and variations in natural conditions (World Bank, 2009). Water accessibility "means" availability of water for use by individual or by a family or household for household purposes; for farm and domestic animals

*Corresponding Author: Dangana, K.

Email: dangana999@gmail.com 
up to normal grazing capacity of the land whether or not the animals are actually owned by such, individual or family, and for the irrigation of land(William, 2006).

\section{Statement of Research Problem}

The world population has been dynamic and this dynamism has impacted on environmental resources to the extent that water shortages may in the future increase dramatically. For example the percentage of households in Niger State relying on vendor services for water supply is about $3.8 \%$, a figure higher than the national average of $1.8 \%$. Furthermore, household access to piped water in Nigeria is only about $6.5 \%$ (UNICEF, 2007)

The case for the study area is alarming because the entire area is made up of rural settlements, small and medium sized urban centers where majority of the population live below poverty line and could not afford water infrastructure such as modern hand or electric pump boreholes. In Nigeria, rural water coverage is far behind both urban and national coverage. Given this scenario, water and water related problems are likely to abound in the area. The complexity of the crisis is underlain by the fact that the poor suffer most from lack of access to these services, and for water they may even pay more, since cost transient cash payment to include time and energy used. Unfortunately access to safe drinking water is far less than $30 \%$ on the aggregate and the unavailability of portable water is a major source of water borne diseases, in particular among the rural and urban poor, which may lead to reduction in life expectancy (FGN, 2004). Alaci (2010) look at household water accessibility in Sothern part of
Kogi State, and identify some challenges to household water accessibility. Adeleye (2014) also assessed problems of water supply and sanitation in Kpakungu Area of Minna Niger State, but to the best of my knowledge nobody had studied household water accessibility in the study area. This is the gap in knowledge which is intended to be bridged by this research on analysis of household water accessibility in the southern part of Niger state of Nigeria. The study therefore attempts to examine the major challenges of household water accessibility in the area. An attempt is also made to recommend possible solutions to the identified problems. Paul (2006) Analyzed the Relationship between Water Accessibility, Use and Health in Muthara, Kenya. His findings are that average water use for the Muthara area is 16.7 L/capita-day including laundry and 12.3 L/capita-day without laundry. These values fall within the Basic Access service level (around 20 L/capita-day). Some of the water sources used by villagers are unimproved and some are improved. George (2010) Assessed accessibility of water services in Kisumu municipality, Kenya. He identified that key challenges to the developing countries is how to increase access to safe water supply to the rapidly growing urban population. The Kenyan study shows that the proportion of households with access to piped water supply within a distance of $200 \mathrm{~m}$ is $77.1 \%$, only $65.6 \%$ of the basic water requirements of the residents are met and that only $25 \%$ of the households access the minimum recommended 50 litres.

\section{Aim and Objectives}

The aim of the study is to examine the determinants of water accessibility in 
the Southern part of Niger State. In an attempt to achieve the above stated aim, the following specific objectives shall be pursued

i. To determine locational efficiency of water facilities in the area.

ii. Determine per capital water consumption in the area.

iii. To examine the spatial variation in water consumption in the area

iv. To examine factors for water demand and supply in the area.

\section{Study Area}

The Study area is located between latitude $8.10^{\circ}$ and $11.8^{\circ}$ North and between longitude' $4.30^{\circ}$ and $7.00^{\circ}$ East. The area is bordered in the north by Paikoro, Maikunkele, and Wushishi Local Government Areas, to the west by Mashegu and Borgu Local Government Areas, to the East by Suleja Local Government and the Federal Capital Territory. While to the south is bordered by River Niger, the border between Niger state and kogi and Kwara. It covers a land Area of about 24, 741 Sq Km (Abubakar, 2003).

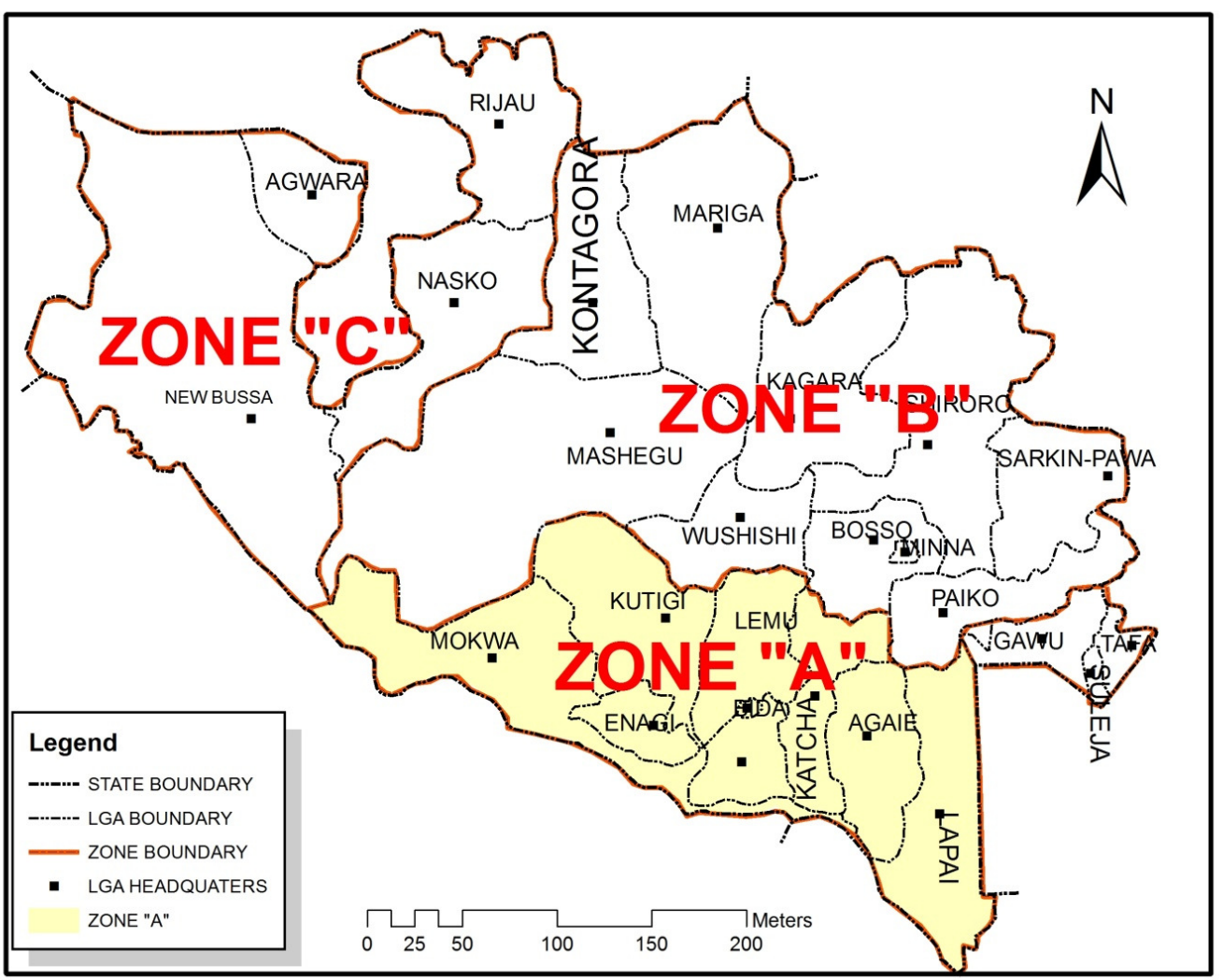

Figure 1: Map of the study area

\section{Theoretical Framework}

The main concept of this discourse is accessibility. In "a theory of access" Ribot et al. (2003) point to the frequent use - yet inadequate definition of the term "access" within property and natural resources studies. Their concern is to move away from more traditional 
property debates on property rights and legal ownership in recognition of the complexity of ways in which access to resources is determined. They point out that a number of other mechanisms that legal rights are at play in shaping access, such as access to technology, capital, identity, networks.

According to Ribot et al. (2003) access is the ability to benefit from things including material objects, persons, and symbols. Access depends on the bundles of powers that individual's holds, which are the means in which actors gain control and maintain access to resources.

\section{Accessibility Indicators}

An indicator is generally what shows what conditions are. Root word of indicator is pointer; describing how an indicator is intended to point towards some desirable state or course of action and something that is used to show the presence or state of a condition or trend. Indicators are not data, rather they are models simplifying a complex subject to a few numbers to be easily grasped and understood by policymakers and the public. Indicators are user driven, and are generally highly aggregated, so that changes or differences in the value of an indicator may be more important than its absolute level. A water accessibility indicator as developed by the World Health Organization (WHO) is presented in the table below.

WHO Water Accessibility Indicators

\begin{tabular}{|c|c|c|c|}
\hline $\begin{array}{ll}\text { Distance Travelled to } \\
\text { Collect water }\end{array}$ & $\begin{array}{l}\text { WHO Standard/ } \\
\text { Remark }\end{array}$ & $\begin{array}{l}\text { Average Time spent To } \\
\text { collect water }\end{array}$ & $\begin{array}{l}\text { WHO Standard } \\
\text { Optimal Access }\end{array}$ \\
\hline$<100 \mathrm{M}$ & $\begin{array}{l}\text { One tap on plot } \\
\text { Within } 100 \mathrm{~m} \\
\text { (Intermediate } \\
\text { accesss) }\end{array}$ & Within 5 minute & Intermediate access \\
\hline $\begin{array}{l}101-200 \mathrm{M} \\
201-500 \mathrm{M}\end{array}$ & $\begin{array}{l}\text { Between } 100 \text { and } \\
1000 \mathrm{~m}\end{array}$ & $\begin{array}{l}5-30 \text { minutes } \\
30 \text { minute }-2 \text { hours }\end{array}$ & Basic access \\
\hline $\begin{array}{l}500 \mathrm{M}-1000 \\
1.1-2 \mathrm{Km}(1.5 \mathrm{Km}) \\
>2 \mathrm{~km}(3 \mathrm{~km})\end{array}$ & $\begin{array}{l}\text { (Basic access) } \\
\text { More than } 1000 \mathrm{~m} \\
\text { (No access) }\end{array}$ & $\begin{array}{l}\text { 2-4 hours } \\
>4 \text { hours }\end{array}$ & No access \\
\hline
\end{tabular}

Source: WHO (2004)

\section{Research Method}

The data for this research was drawn from water users and water providers, this include households, water providing agencies, water vendors and government official documents.

\section{Types and Sources of Data}

The data for this study were derived from Primary and Secondary sources.

\section{Primary Sources of Data}

The primary sources of data include questionnaire, observation, and personal interviews of Heads of household, Officials of Water Board Resident in the Area NGOs and water vendors.

\section{Secondary Sources of Data}

The secondary sources of data include relevant publications, government documents, statistical maps and records including government financial budget, allocation and expenditure on capital water project and materials obtained from the internet. 


\section{Sampling Frame and Sampling Technique}

The sampling technique employed in this research is a combination of purposive, stratified and simple random sampling. To arrive at the choice of the sampled Local Government Areas for questionnaire administration, purposive sampling method was used. The choice of Bida is to have insight to water accessibility problem in urban centres and Lapai and Edati have both semiurban and rural communities under them and this areas would reveal water problem in semi-urban and rural areas.

The selection of localities in each sampled LGA was based on stratified random sampling; because localities vary in size and distribution and to ensure a representative and spatial coverage. With the aid of topographical map, localities sampled were made to maintain at least five (5) kilometers apart, All localities selected have population of not less than (300) people and it based on the size of population that they were stratified.

The choice of household was based on simple random sampling. The reason is because area being a fairly homogenous society in terms of socio-cultural traits, experience and responses are not likely to vary significantly, however, in a large population it is important to give every individual equal chance of being selected. The combination of these procedures yielded three (3) Local Government Areas, fifteen (15) Localities, five (5) per Local Government Area.

The largest localities in each Local Government Area sampled. For the purpose of sampling in each of these three Local Government Areas, 2006 population was updated to 2013 using $3.4 \%$ growth rate for the state and the updated figured was used to calculate sample size using Yaro Yamane formulae. Thus

Where

$$
\mathrm{n}=\frac{N}{1+N(e) 2}
$$

$\mathrm{n}=$ the Sample size

$\mathrm{N}=$ the finite population

$\mathrm{e}=$ level of significance (or limit of tolerable error) (0.05)

$1=$ unity $(\mathrm{a}$ constant

Table 1: The sample sizes obtained using Yaro Yamane formulae

\begin{tabular}{llll}
\hline & Local Government Area. & $\begin{array}{l}\text { Total Population } \\
\text { (2013 estimate) }\end{array}$ & Sample Size \\
\hline 1 & Bida & 117045 & 399 \\
2 & Edati & 88930 & 398 \\
3 & Lapai & 66270 & 398 \\
& Total & & 1195 \\
\hline
\end{tabular}

\section{Questionnaire Administration}

Questionnaire was administered randomly using the table of random sampling; this was done using 3 research assistants in each of the wards. The administration of questionnaire was done under the supervision of the researcher.
Discussions was held with the water users, water vendors, NGO's and Officials of the Niger state Water Board resident in the area on their contributions in the provision of water in the community. 


\section{Method of Data Analysis}

The data was sorted out using frequency tables; the information was then summarized in tabular form. The percentages and means for various Local Government Areas were sorted out, after which cumulative percentage was calculated. This was used to generalize the information on the study area. Percentages were used for easy comparison of the water accessibility levels and also to show spatial variation of water accessibility in the area.

\section{Result and Discussion}

Distribution of how Water is sourced by the Respondents

Table 1 below revealed how water is sourced by respondents, Accessibility deals with ease with which a resource can be obtained. How water is sourced indicate ease with which water is obtained, it is an indicator of accessibility that tends to look at whether the respondents obtain water within the compound or outside the compound or within the locality or outside the locality. It is an indicator that shows the level of access to water.

Table 1: How Water is sourced by Respondents

\begin{tabular}{|c|c|c|c|c|c|c|c|c|}
\hline \multirow{2}{*}{$\begin{array}{l}\text { How water } \\
\text { Is sourced }\end{array}$} & \multicolumn{2}{|c|}{ Lapai LGA } & \multicolumn{2}{|c|}{ Bida LGA } & \multicolumn{2}{|c|}{ Edati LGA } & \multirow{2}{*}{$\begin{array}{l}\text { Cumulative } \\
\text { Frequency } \\
\end{array}$} & \multirow{2}{*}{$\begin{array}{l}\text { Cumulative } \\
\text { Percentage }\end{array}$} \\
\hline & Freq & $\%$ & Freq & $\%$ & Freq & $\%$ & & \\
\hline Door to Door & 5 & 1 & 15 & 4 & & & 20 & 2 \\
\hline $\begin{array}{l}\text { Within the } \\
\text { Compoud }\end{array}$ & 59 & 16 & 90 & 25 & 129 & 34 & 278 & 24. \\
\hline $\begin{array}{l}\text { At home outside } \\
\text { the Compound }\end{array}$ & 135 & 35 & 173 & 47 & 166 & 45 & 474 & 42 \\
\hline Within Locality & 170 & 44 & 74 & 20 & 72 & 19 & 316 & 28 \\
\hline Outside Locality & & & 3 & 1 & & & 3 & 0.26 \\
\hline $\begin{array}{l}\text { Through } \\
\text { Vendors }\end{array}$ & 16 & 4 & 11 & 3 & 9 & 2 & 36 & 3 \\
\hline Total & 385 & 100 & 366 & 100 & 376 & 100 & 1127 & 100 \\
\hline
\end{tabular}

Table 1 shows how water is sourced by the respondents. In the area only $2 \%$ of the respondents have door to door service, $24 \%$ obtain water within their compound and $42 \%$ obtain water outside their compound. This revealed that majority of respondents have to travel some distance to obtain water and also time is been wasted to wait for turn to fetch water. This therefore constitutes constraints to accessibility in the area.

\section{Domestic Water Sources of the Respondents \\ Domestic water source is very} crucial, because it determine whether the source is portable or not. It also determines how free the household will be from water related disease. The sources of water in the area include well, river, electric and hand pump borehole. 


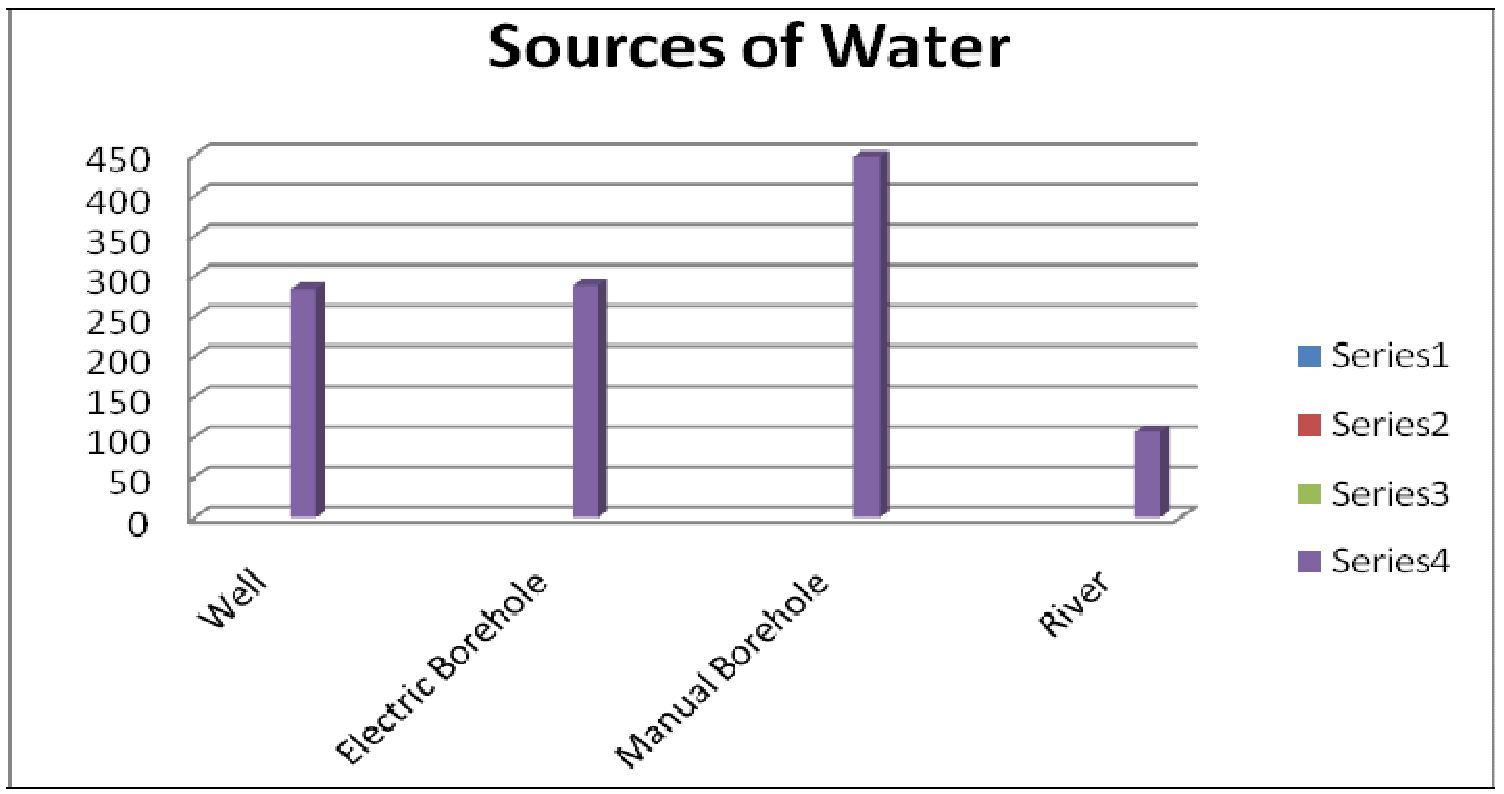

Figure 2: Domestic Water Sources of Respondent

Figure 2 above reveals the major sources of water in the area. It shows that the major sources of water in these areas are well, river, electric and hand pump borehole and this sources constitute $90 \%$ of water sources available to respondents in the area. The sources of water supply available can influence the quantity of water at the disposal of individual or household. This traditional sources of water supply such as river, lakes and springs have remained central in regional water supply (rural areas especially) in the developing countries. Well for example over the years have been the main sources of water in many communities. They have taken dominant position in areas where distance and relative availability of rivers proven to be major water supply constraints. These sources of water are plagued with many problems, which reduces their utility and that is why only few respondents depend on them as their sources of water for domestic uses.

\section{Regularity of Water Supply by the Vendors}

The regularity of vendors sometimes posed challenge to those that depend on vendors as their sources of water. In most cases vendors have more than one customer and would like to satisfy all. This situation put in a serious fix to satisfy all the customers, thereby making it impossible for them to supply their customers with water at the right time. Accessibility is hampered with when a resource is not made available when it is needed, the challenge for those that depend on vendor sources are therefore two, i.e money paid for the service and inconveniences of not having it at the right time. 
Table 2: Regularity of Water Supply by the Vendors

\begin{tabular}{lllllllll}
\hline $\begin{array}{l}\text { Vendor } \\
\text { Services }\end{array}$ & \multicolumn{2}{l}{$\begin{array}{l}\text { Lapai Local } \\
\text { Government }\end{array}$} & \multicolumn{2}{l}{$\begin{array}{l}\text { Bda Local } \\
\text { Gvernment }\end{array}$} & $\begin{array}{l}\text { Edati Local } \\
\text { Government }\end{array}$ & $\begin{array}{l}\text { Cumulative } \\
\text { Total }\end{array}$ & $\begin{array}{l}\text { Cumulative } \\
\text { Percentage }\end{array}$ \\
\hline & Freq & Per & Freq & Per & Freq & Per & & \\
Daily & 37 & 10 & 25 & 7 & 10 & 3 & 72 & 7 \\
2days interval & 5 & 1 & 12 & 3 & 6 & 2 & 23 & 2 \\
Fortnightly & 7 & 2 & 8 & 2 & 3 & 1 & 18 & 2 \\
Weekly & 4 & 1 & 10 & 3 & & & 14 & 1 \\
None & 332 & 86 & 311 & 84 & 357 & 94 & 1000 & 88 \\
& 385 & 100 & 366 & 100 & 376 & 100 & 1127 & 100 \\
\hline
\end{tabular}

Table 2 shows that majority of those households that depend on vendor services indicated that vendor's relative regularity is mainly on daily basis. This is attested to by about $7 \%$ that depend on vendor service as their source of water daily, $2 \%$ of the respondents obtain water from vendors at 2 days interval, while $1 \%$ obtain water from vendors weekly and $88 \%$ do not obtain water at all from vendors, this shows that about $12 \%$ depend on vendor services.

Amount Spent Daily on Water by Respondent
Amount spent on water by respondents that dependent on vendor supply as sources of water. Accessibility is constrained by how much one paid before obtaining a resource. In events that one has to pay before getting access to resource and eventually, you have no money to pay then accessibility become problem. In developing Nations where most people live below poverty line, some cannot afford three square meals, paying for water in addition to existing problem of food should be of great concern to the government

Table 3: Amount Spent on Water Daily by Respondents

\begin{tabular}{lllllllll}
\hline $\begin{array}{l}\text { Amount Spent } \\
\text { Daily on Water }\end{array}$ & \multicolumn{2}{l}{$\begin{array}{l}\text { Lapai Local } \\
\text { Government }\end{array}$} & \multicolumn{2}{l}{$\begin{array}{l}\text { Bida Local } \\
\text { Government }\end{array}$} & \multicolumn{2}{l}{$\begin{array}{l}\text { Lapai Local } \\
\text { Government }\end{array}$} & $\begin{array}{l}\text { Cumulative } \\
\text { Total }\end{array}$ & $\begin{array}{l}\text { Cumulative } \\
\text { Percentage }\end{array}$ \\
\hline N20- N100.00 & 7 & Per & Freq & Per & Freq & Per & & \\
N101- N200.00 & 24 & 6 & 11 & 3 & 6 & 2 & 24 & 2 \\
201- N400.00 & 18 & 5 & 9 & 9 & 9 & 3 & 65 & 6 \\
400 and Above & 4 & 1 & 3 & 1 & & 1 & 31 & 3 \\
None & 332 & 86 & 311 & 84 & 357 & 94 & 1000 & 88. \\
Total & 385 & 100 & 366 & 100 & 376 & 100 & 1127 & 100 \\
\hline
\end{tabular}

The table 3 above is a summary of amount spent on water on daily basis by some respondent that dependent on vendor services. In the area $2 \%$ of the respondents spent between N20.00 N100.00, 6\% spent $\$ 101.00-\$ 200.00$ and $3 \%$ spent between $\$ 201.00$ $\$ 400.00$. In the area only few respondents spent money on daily basis to obtain water. This is because to spend money on daily basis to obtain water a lot of money would be expended.

Distance Travel to Obtain Water by the Respondents

The distance travelled to obtain water is a serious measure of accessibility, as it 
determines whether or not respondents would be able to obtain enough for domestic and other uses. Where someone would have to travel for long distance to obtain water, this may be a barrier to accessibility, because he may not be able to obtain enough that would meet up with his demand.

Table 4: Distance Travel to Obtain Water by the Respondents.

\begin{tabular}{|c|c|c|c|c|c|c|c|c|}
\hline \multirow{2}{*}{$\begin{array}{l}\text { Distance Travel } \\
\text { To obtain water. }\end{array}$} & \multicolumn{2}{|c|}{$\begin{array}{l}\text { Lapai Local } \\
\text { Government }\end{array}$} & \multicolumn{2}{|c|}{$\begin{array}{l}\text { Bida Local } \\
\text { Government }\end{array}$} & \multicolumn{2}{|c|}{$\begin{array}{l}\text { Edati Local } \\
\text { Government }\end{array}$} & \multirow{2}{*}{$\begin{array}{l}\text { Cumulative } \\
\text { Total }\end{array}$} & \multirow{2}{*}{$\begin{array}{l}\text { Cumulative } \\
\text { Percentage }\end{array}$} \\
\hline & Freq & Percentage & Freq & Per \% & Freq & Per \% & & \\
\hline$<100$ Metres & 167 & 43 & 100 & 27 & 107 & 28 & 374 & 33 \\
\hline $1-2 \mathrm{Km}$ & 137 & 36 & 161 & 44 & 97 & 26 & 395 & 35 \\
\hline $2-4 \mathrm{Km}$ & 17 & 4 & & & 43 & 12 & 60 & 5 \\
\hline No Distance & 64 & 17 & 105 & 29 & 129 & 34 & 298 & 27 \\
\hline & 385 & 100 & 366 & 100 & 376 & 100 & 1127 & 100 \\
\hline
\end{tabular}

River and well are the traditional sources of water, and it is the backbone of some community water supply in the study area. The centrality of this supply source relates to its function as a factor of settlement location. Before the discovery or emergency of sources such as boreholes and vendor services, rivers play important role of being the main sources of community water supply with the complimentary support from rainfall. In the area $33 \%$ of the respondents travel for 100 meter to obtain water, $35 \%$ of the respondent travelled between $1-2 \mathrm{Km}$ to obtain water, $5 \%$ of the respondents travelled $2-4 \mathrm{Km}$ to obtain water, while $27 \%$ travelled no distance to obtain water. This therefore revealed that distance travelled to obtain water constitute a barrier to accessibility in the area

Time Spent Daily on Fetching Water by Respondents with no Taps

The time spent daily on fetching water by respondents with no tap as obtain in the field is here by presented in table 5. Time is precious, the fact that most of those involved in scotching for water are mostly children of school age that are supposedly to be in the school at the time they are struggling to get water. Their time is wasted scotching for water, aside children of school, women are also involved in fetching water and spent time that would have been used in another economic activities.

Table 5: Time Spent Daily on Fetching Water by Respondents.

\begin{tabular}{|c|c|c|c|c|c|c|c|c|}
\hline \multirow[t]{2}{*}{$\begin{array}{l}\text { Time Spent } \\
\text { To obtain water }\end{array}$} & \multicolumn{2}{|c|}{$\begin{array}{l}\text { Lapai Local } \\
\text { Government }\end{array}$} & \multicolumn{2}{|c|}{ Bida LGA } & \multicolumn{2}{|c|}{$\begin{array}{l}\text { Edati Local } \\
\text { Government. }\end{array}$} & \multirow[t]{2}{*}{$\begin{array}{l}\text { Cumulative } \\
\text { Total }\end{array}$} & \multirow[t]{2}{*}{$\begin{array}{l}\text { Cumulative } \\
\text { Percentage }\end{array}$} \\
\hline & Freq & $\begin{array}{l}\text { Per } \\
\%\end{array}$ & Freq & $\begin{array}{l}\text { Per } \\
\%\end{array}$ & Freq & Per $\%$ & & \\
\hline 5-30Minutes & 87 & 23 & 164 & 45 & 129 & 34 & 380 & 34 \\
\hline 1hour & 229 & 59 & 192 & 52 & 166 & 44 & 587 & 52 \\
\hline $\begin{array}{l}\text { 2hours } \\
\text { 3hours }\end{array}$ & 69 & 18 & 10 & 3 & 81 & 22 & 160 & 14 \\
\hline Total & 385 & 100 & 366 & 100 & 376 & 100 & 1127 & 100 \\
\hline
\end{tabular}


The time spent to obtain water is critical in measuring water accessibility, the most formidabe challenge to dug wells or sank boreholes as sustainable sources of household water has to do with time spent in obtaining the water out of the well, boreholes; energy spent, quality of the water obtained and where these facilities are not located at the compound level, then distance becomes another challenge. From table 5.15, that summarized distance travelled to obtain water, in the area, $34 \%$ of the respodents spent 5-30minutes to obtain water, $52 \%$ of the respondents spent 1hour to obtain water $14 \%$ spent 3hours to obtain water. The highest percentage of respondents spent 1hour to obtain water. It also shows that majority of the respondents has distance as constriants to accessibility to water, as they have to travel some distance to obtain water.

Table 6: Household Per Capita Water Consumption.

\begin{tabular}{|c|c|c|c|c|c|c|c|c|c|}
\hline & \multicolumn{3}{|c|}{ Lapai L G A } & \multicolumn{3}{|c|}{ Bida LGA } & \multicolumn{3}{|c|}{ Edati LGA } \\
\hline & Freq & $\begin{array}{l}\text { Mean } \\
\text { Hhsize }\end{array}$ & $\begin{array}{l}\text { Per } \\
\text { Capita } \\
\text { Water }\end{array}$ & Freq & $\begin{array}{l}\text { Mean } \\
\text { Hhsize }\end{array}$ & $\begin{array}{l}\text { Per } \\
\text { Capita } \\
\text { Water }\end{array}$ & Freq & $\begin{array}{l}\text { Mean } \\
\text { Hhsize }\end{array}$ & $\begin{array}{l}\text { Per } \\
\text { Capita } \\
\text { Water }\end{array}$ \\
\hline $0-45$ liters & 15 & 2 & 22. & 9 & 1 & 27 & 21 & 2 & 22 \\
\hline 68 liters & 67 & 3 & 22 & 48 & 3 & 22 & 85 & 3 & 22 \\
\hline 115liters & 101 & 5 & 22.6 & 63 & 5 & 22.6 & 129 & 6 & 18 \\
\hline 160 liters & 89 & 7 & 22 & 103 & 7 & 22 & 53 & 7 & 22 \\
\hline 205 liters & 59 & 9 & 22.5 & 33 & 7 & 29 & 23 & 8 & 25 \\
\hline 250 liters & 34 & 10 & 25.3 & 61 & 9 & 28 & 35 & 10 & 25 \\
\hline$>280$ liters & 20 & 13 & 21 & 49 & 10 & 28 & 30 & 11 & 25 \\
\hline Average & & & 19 & & & 26 & & & 22 \\
\hline $\begin{array}{l}\text { Cummulative } \\
\text { Average }\end{array}$ & & & & 22 & & & & & \\
\hline
\end{tabular}

The table above show per capita water consumption ranges from 6 liter to 29 liters. Although variations exist in per capita water consumption based on location, vailability and status of the family. The average per capita water consumption in Bida is 26 liter per person, in lapai 19 liter per person, while in Edati 22 liter per person. However this gives an average of 22 Liters per person as capita accessibility status of the area. From the table majority of the households have within the range of 1222 liters per capita water. The internationally recommended; World health Organisation (WHO) per capita water is 45 liters per day.

Findings
1) Only $2 \%$ of the respondents have door to door service water delivery, $42 \%$ obtain water outside their compound, $28 \%$ obtain water within locality but not within the vicinity of the compound, with $0.26 \%$ obtaining water outside their locality.

2) $25 \%$ of the respondent depend on well, $26 \%$ depend on electric pump borehole, $40 \%$ depend on hand pump borehole, and $9 \%$ depend on river with average of 80 persons per borehole and $12 \%$ depending on vendor services for water. $2 \%$ of those that depend on vendor services spent N20.00 to N100.00 daily, 6\% spent between N100, 00 to N200.00 
and $3 \%$ spent $\mathrm{N} 200$ to $\mathrm{N} 400.00$ per day.

3) $33 \%$ travel less than 100 metres to obtain water, $35 \%$ travelled 1 to 2 kilometres to obtain water, $5 \%$ travelled between 2 to 4 kilometres to obtain water, with only $27 \%$ travelling no distance to obtain water. $34 \%$ spent 5 to 30 minutes to obtain water, $52 \%$ spent 1 hour to obtain water, and $14 \%$ spent 2 hours to obtain water.

4) Per capita water consumption varies from 18 litres to 25 litres per person per day, however average per capita water consumption of Lapai Local Government is 19 liters, Bida 26 liters and Edati 22 liters. While average per capita water consumption for the area is 22 liters per person.

\section{Conclusion}

Accessibility to adequate and safe water supply is important and can influence socio-economic progress of human settlements and the healthy living of the dwellers. The provision of this basic service in the Southern part of Niger State is largely inadequate thereby creating a situation of poor water accessibility in the area. Domestic water supply in the area is mainly interplay of different traditional water supply sources and few available sources of modern boreholes which are grossly inadequate.

Household water accessibility is seriously affected by the factors of income, time spent to obtain water and distance travelled. The impact of inadequacy, which is the most critical manifest strongly on households in terms of waiting time and distance taken to obtain water and low per capita water availability. This study shows the attitude of Government to provision of water in the area. The political will by those in the government in the form of sectoral allocation for the provision of water infrastructure is the major challenge. Another challenge in some part of the study area is that there is complete absence of electricity from the National grid which would have been used to facilitate the functioning of the available water infrastructure.

\section{Recommendations}

The recommendation arising from the findings of this study are put forward as follows.

Most importantly, one would point out that solving the problem of water need of the area requires commitment and political will by the government and also both pro-active and reactionary approach to water planning principles.

Government at all levels should see provision of water to the citizens as their social responsibility and therefore should be committed to water infrastructural development, so as to solve the problem of inadequacy of water infrastructure in the area.

The findings of the study are

Only $2 \%$ of the respondents have door to door service water delivery, $42 \%$ obtain water outside their compound, 28\% obtain water within locality but not within the vicinity of the compound, with $0.26 \%$ obtaining water outside their locality.

$25 \%$ of the respondent depend on well, $26 \%$ depend on electric pump borehole, $40 \%$ depend on hand pump borehole, and $9 \%$ depend on river. With average of 80 persons per borehole and $12 \%$ depending on vendor services for water. $2 \%$ of those that depend on vendor services spent $\mathrm{N} 20.00$ to $\mathrm{N} 100.00$ daily, $6 \%$ spent 
between N100, 00 to $\mathrm{N} 200.00$ and 3\% spent N200 to N400.00 per day.

$33 \%$ travel less than 100 metres to obtain water, $35 \%$ travelled 1 to 2 kilometres to obtain water, $5 \%$ travelled between 2 to 4 kilometres to obtain water, with only $27 \%$ travelling no distance to obtain water. $34 \%$ spent 5 to 30 minutes to obtain water, $52 \%$ spent 1 hour to obtain water, and $14 \%$ spent 2 hours to obtain water.

Per capita water consumption varies from 18 litres to 25 litres per person per day, however average per capita water consumption of Lapai Local Government is 19 liters, Bida 26 liters and Edati 22 liters. While average per capita water consumption for the area is 22 liters per person.

$66 \%$ of the respondents indicated inadequacy of water supply, with $34 \%$ indicating adequacy of water supply. $9 \%$ of the respondents indicated that Niger state government is trying in the provision of water infrastructure, $48 \%$ described effort by state government as poor, while $78 \%$ described efforts of local government as poor.

\section{References}

Adeleye. B, Medayese, Okelola. O (2014). Assessed Problem of Water Supply and Sanitation in Kpakungu Area of Minna. Glocalism Journal of Culture, Politics and Innovation. 32-46.

Alaci, D.S.A. (2010). Assessment of Household Water Accessibility in Eastern Kogi State of Nigeria. Unpublished Thesis submitted to Department of Geography University Abuja. MDG's
Organized by UNECA and FGN; 7-9 May, 2009 Trascorp Hilton Hotel Abuja, Nigeria. Available at www.uneca.org/acgd/events

FGN (2004). Draft National Rural Water Supply and Sanitation Programme: A Strategic Framework. March 2004

George, G.W. and George M.O. (2010). Accessibility of Water Services in Kisumu Municipality, Kenya. Journal of Geography and Regional Planning, 3(4): 114-125.

Paul, M.K. (2006). Analysis of the Relationship Between Water Accessibility, Use and Health in Muthara, Kenya. M Sc Thesis Submitted to Department of Environmental Engineering Michagan Technology University.

Ribot, J.N. and Peluso, N.L. (2003). A Theory of Access. Rural Sociology, 68(2): 153-181

Uzoagulu, A.E. (1998). Practical Guide to Writing Research Project Report. Published June, 1998, Pg 66

UNICEF (2007). Water, Sanitation and Hygiene in Nigeria, February 2007.

WWAP (2003). Water for people, Water for Life. The United States World Water Development Report. World Water Assessment Programme.

Williams, D.T. (2006). Organochlorine Pesticide Levels in Ottawa Drinking Water, 2006. Pesticide Monitoring. Journal 2007, 12,163.

World Bank, (2009): World Development Report: Infrastructure for development. London Oxford University Press.

World Health Organization (2004). Water Sanitation and Health (WSH) Water, Sanitation and Hygiene links to Health, Facts and Figures. From http://www .who.int/whr/2004/en/whr02_enpdf. 